\title{
The Impact of New Media Technology on Electoral Victory: Focus on 2015 General Election in Nigeria
}

\author{
Chukwuemeka Okafor \\ Department of Government and Public Administration, Baze University, Abuja, Nigeria \\ Email: emeka.okafor250@gmail.com \\ Sunday Maduka Agu \\ Department of Administration, National Film and Video Censors Board, Abuja, Nigeria \\ Email:agusunnyo@gmail.com
}

Received: 19 April 2019; Revised: 14 May 2019; Accepted: 3 June 2019; Published: 26 June 2019

\begin{abstract}
Election is a process of selecting people to hold political offices and authority on behalf of the electorate. It is a very important aspect of every democratic process. The 2015 general election in Nigeria was very unique. It proved wrong all predictions of recording high rate of violence and lack of free and fairness. The electoral outcome defiled all these predictions and created a new landmark that has never been recorded in the history of elections in Nigeria. For the first time, there was high rate of youth involvement and political participation and the incumbent president was defeated despite huge propaganda and scandals that trailed the opposition. An uptight and laid back analogue opposition presidential candidate defeated a more vibrant and very amiable incumbent in an election adjudged to be free and fair. This paper seeks to investigate what actually happened and what informed the drastic change of attitude of young people in the electoral process. Descriptive and documentary methods were used in data collection and analysis. The findings show that new media technology is a very potent tool of mass communication and mass mobilization which cannot be overlooked in ensuring that citizens participate effectively and efficiently in the democratic process. The paper recommends the effective use of new media technology by politicians and political parties as a tool to enhance political mobilization for electoral victories.
\end{abstract}

Keywords: Media technology, Electoral victory

\section{Introduction}

An election is described as a process that gives the members of an organisation or a community the latitude to choose representatives that will hold elective offices on their behalf (Oji, 1997:98). Elections are used to select leaders of local, State, and National Governments. The decision of who holds political office at these levels allow the public to express their views on how they want the policies, programs, actions and the directions of the incoming government's activities. Tom Baxter (1996: 205) reiterates that the threat of reelection compels the incumbent government to be accountable and transparent in their actions and to conduct themselves in a responsible manner, taking into cognizance popular interests and wishes of the electorate when making policy decisions.

In Nigeria, elections are held every four years. The responsibility of organising general elections rests with the Independent Electoral Commission (INEC) and The Electoral Act guides the conduct of these elections. The Electoral Act specifies how elections are administered, determines the boundaries and rules for selecting candidates that will stand for elections by political parties. The electoral commission also outlines the process of declaring the winners in elections, conducts and rules guiding electioneering campaigns and specifies the time allowed for the parties in the electoral process to seek redress in courts. The Independent Electoral Commission delineates the electoral wards and staff polling centres, verify the eligibility of candidates who vote and are voted for in elections, conducts elections and announces the winners of the elections (Chukwu, 2007:5).

Historically, the media has been recognised as the cornerstone of democracy and have played very prominent roles in swaying political discussions and the outcome of elections. When the media is balanced in its reporting of elections and electoral processes it fosters transparency and prompt dissemination of 
important electoral information (Nwabueze, Obasi \& Obi, 2012:9). In a well-planned political advertisement, candidates in elections use the media to market their ideologies, manifestos etc. and to increase their interactions with the electorate. In recent political campaigns, extensive use of the radio and television have supplemented the direct appearances by candidates seeking election on campaign arenas. The most frequently used broadcast technique is the television "spot advertisement". Spot advertisement of between 15 to 60 seconds can be very effective to emphasize issues, ideology and personal qualities of aspirants. These advertisements attempt to "market" the candidate to the electorate, create favourable images of the candidate and in most situations negative images of the opponents. It provides a link between the candidate and groups in the community, and communicates the candidate's stand on selected issues to them. Spot advertisements often make use of sound bites, short and catchy statements intended to be implanted permanently on the memory of voters. Spot advertisements at times slant negatively, with the aim of criticizing the opponent. A very successful negative spot advertisement used in the 2015 general election in Nigeria was the "Change" slogan used by the APC which was constantly repeated on the airwaves throughout the campaign period (Udensi, 2015:4). However, this paper discusses the new media technology which is a different and new angle of media campaign. The 2015 general election shows how huge the advantages of a well-planned and effectively used new media technology can be in swaying electoral victory to the side of any party or individual that effectively uses it.

\section{Conceptual Discourse}

In America, which is said to have the best and legally bound democratic framework, the press is also referred to as the "Fourth Estate". The term "Fourth Estate" dates back to the $18^{\text {th }}$ century Britain. The term suggests a very strong force both in the society and government. Consequently, the press is equated to the three recognised "Estates" as at that time. The three recognized estates include the "Nobility", the "Clergy" and the "Commoners". Today the term "Fourth Estate" still indicates that the press plays a very special role in the society and system of governance. However, the role of the press could be ambiguous and controversial. Journalists are neither elected by the people nor are they appointed or confirmed by elected officials (MichaelKinsley 2005:23). Michael-Kinsley (2005) further states that what gives the journalists who are mostly private citizens and are working privately the influence on how the country is governed includes the belief that the profession is actually contained in the constitution. Moreso, the freedom of speech reflects the claim that the forerunners of democracy recognised the role of the press in ensuring good governance, growth and sustainable development.

It is not clear whether the founding fathers of democracy meant that "the freedom of speech and the press" refers to journalism profession or whether they simply meant that freedom of speech includes print as well as the broadcast media. A more acceptable defense of the role of the press on swaying actions of the government may be the power of persuasion. The press can not cause any government policy to change without convincing the people or their representatives that the policy ought to change. Therefore, it does not matter if the journalists are elected or not. The $21^{\text {st }}$-century press is also referred to as the media. Like "Fourth Estate," the term "Media" reflect a certain understanding about the role of the press in society. The media literally means the various technologies that convey information from Ink on paper to Telephones, Radio, Television and the Internet etc. Notwithstanding its literal meaning, the media implies information and those who handle it, which actually is more than just the newsprint and electronic broadcasts. In this age of Information technology, platforms used for information dissemination have inevitable influences on the society and government (Microsoft Encarta, 2009).

In most cases, the media have influenced society positively. The media exposes the flaws of governments, businesses, academia or other aspects of the democratic and capitalist society. It also helps in the correction of these flaws. But the views about the role of the media is not widely accepted outside the media circle. Opinion polls about the role of the media have consistently shown that the media is unpopular especially to those that it opposes. While complaints about the popularity of the media vary, many of them can be distilled into two basic ideas. One is that the journalists are biased and that their reports are not objective and balanced. On the other hand, the media is being accused of exposing matters that ought to be nobody else's business and that they trample on the citizens' right to private life. People who complain about the media being biased often misunderstand the key point, that there is a big difference between the media being biased and having an opinion. It is natural that as they get involved in these activities they develop opinions about these issues and events. Those inclined to charging the press as being biased invariably have very strong political opinions and leanings with those being criticized by the media. But they rarely see their own opinions as being biased. Most

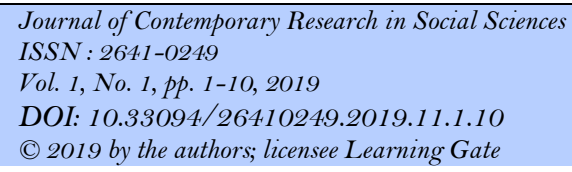


times accusing the media of bias simply means that "the media disagrees with them." But being actually biased is when the media allows their opinions get in the way of fair, balanced and accurate reporting, (MichaelKinsley, 2005:4).

The media have contributed to this confusion and negative opinion about them by sometimes suggesting that they, unlike ordinary people, have a special responsibility to draw no conclusions, neither do they have opinions about the issues or events that they cover. This is totally wrong, of course, the media do not have such a gift and therefore they cannot have such a responsibility. In some European countries, the media and media institutions have unconcealed political opinions and views especially about the government, political activities and events. In a way, this is apt, but it does not take away the duty of being fair and objective in their reporting from the media. But it relieves the media of the pretence of having no opinion. It therefore, gives the reader or viewer the opportunity to know the disposition of the media about the story. This is the major advantage of the new media over the press with regards to political discussions, events and activities. The new media creates a platform for every individual to express his or her own opinion. It also allows key political actors to react to these opinions and at the same time interact with the wider society which creates a sense of belonging and acceptance among the members of the society. This is a very important aspect of the new media that was not available to the old media. Dukar (1999:24) is of the view that this great landmark of the new media technology manifested in the victory of the APC in the 2015 general election in Nigeria.

Recent developments and advancements in information technology have to a very large extent given birth to the new media. The new media is a computer-based technology that facilitates the creation and sharing of information, ideas, career, interests and other forms of expressions via virtual communications and networks. This interaction is mainly between people with similar interests and ideas. This new media technology provides social media sites, blogs, platforms, twitter, chat forums and groups, made citizenship participation, information and knowledge sharing, interaction and empowerment of a larger citizen population possible (Elechababi 2015:4).

From the late 1990s, political parties started using the internet as campaign tools. Candidates maintained, Twitter Handles, Facebook Accounts, WhatsApp Chat Numbers, Forums and Groups, Instagram Accounts, Weblogs or Blogs, and Websites etc. The candidate's profile, views, opinions and political ideology and other materials used to solicit support for the candidate were made available to the electorate through these platforms. Voters visiting a candidate's website can also be directed on how to get involved and make donations towards supporting the candidate's bid for an elective position. At times a candidates' supporter can also sponsor websites and blogs, spreading the candidate's vision and agenda. The candidate themselves participate in the internet "chats" with their supporters. In the year 2000 John McCain a United States Senator used the new media to mobilize people, attract donations and sponsorship for his bid of the Republican presidential nomination which was unsuccessful. Governor Howard Dean of Vermont also utilised the new media platforms fully as major campaign medium during the 2004 presidential elections, (Karen-Yankavich 2005: 12).

Political observers attribute the increase in the new media in electioneering campaigns especially during fundraising to the passage of the Bipartisan Campaign Reform Act of 2002 in the United States of America. In some countries, laws restrict the amount a supporter can contribute to support a candidate or political parties. These laws prompted the necessity for campaign funds to be raised from a large number of individuals who the law allows donating not more than $\$ 2,000$ to each candidate per election. The new media platform created avenues through which candidates contesting for political offices can get in contact with a large number of people and solicit for funds and support from them at a relatively very low cost. It is on record that some candidates recovered about $98 \%$ of the funds they expended in elections through donations made in their favour through their websites and other new media platforms because of its low-cost advantage.

The new media technology is an exception to the rule of the importance of money in politics. The new technology approach makes it possible for political candidates to raise large sums of money in small contributions from their supporters by appealing to them directly and having one on one contact with their support scattered in a very wide geographical areas. Governor Howard Dean though he lost the Democratic presidential primaries made very effective use of the new media in raising the money he used to fund his presidential ambition between 2003 and 2004. In spite of the success recorded by the introduction of the new media technology in the political process the conservative negative opinion inherent in the other elements against its introduction in politics have not changed. Politicians both in Europe and Africa have copied the American's political model which introduced intensive money and technology in political campaigns. American political consultants have shown politicians all over the world how advantageous the use of the new media 
technology in politics could be. Mathew Ellis (2006: 5) insists that this new approach to politicking, especially in Europe, is sometimes referred to as the "Americanization" of the political processes.

\section{The New Media Technology}

The new media technology popularly known as the social media can be described as a variety of internetenabled activities, such as photo sharing, blogging, social gaming, social networks, video sharing, business networks, virtual worlds and Chats etc. From a private social angle, the social media is used to keep in touch with friends and extended family members. It is a network for career opportunities, locating family members and friends all over the globe who share common interests, ideas, careers, views, ideas, opinions and goals etc. Those who engage in these activities are part of a virtual social network. For businesses, social media is an indispensable tool for finding and engaging customers, sales, advertising and promotion, gauging trends and offering customer services. Politicians and governments use social media as a tool for engaging and interacting with their constituents, supporters and voters (Adibe, Odoemelam \& Chibuwe 2011: 12). The contribution of the new media in business, governance and politics have so far been very significant. The new media facilitates communication with customers, party supporters and the citizens thus, enabling them to interact with each other through the new media platforms. It has the ability to generate feedbacks from them and this helps in channelling focused marketing, campaigns, and developmental efforts. It also helps in promoting products, services, and democratic dividends by enabling them to be more focused, timely and exclusively directed to the target population. According to Godfrey (2015:10), it assists in building lasting relationships, through loyalty and interactive programs that are linked through the new media.

\section{Common Features of the New Media}

The rapid pace of changes in the modes of business, political and social interaction prompted by the new media technology and its users, means that the meaning and concept of the new media must consider this rapid rate of changes that are constantly evolving. However, all new media platforms share the following characteristics:

- It is interactive and Web-based;

- Personalized features and user-generated profiles;

- Contents are generated by the users and includes photos, videos, Chats, Messages, Games, Conversations, Comments, Views, Ideas and virtual reality contents etc.

- Connections between users are facilitated by the platform.

A conservative estimation shows that about $81 \%$ of Americans were using the new media as at 2017 , and an increase to $90 \%$ of the new media usage is anticipated in the next 10 years. Over $80 \%$ of an individual's online time is spent on the new media. As of 2005 , the percentage of adults using the new media was about $5 \%$ of the global population, this translates to about 1.96 billion new media users worldwide. The new media usage is expected to rise to 2.5 billion or $12.2 \%$ of the world's population by the end of 2018 . According to the Pew Research Center, the new media users are the younger population. About $90 \%$ of people between the ages of 18 to 35years use at least one form of the new media platform or the other. The new media usage is relatively high among the more educated and relatively wealthy people. The United States and China are currently leading the list of new media usage globally (Doris-Graber, 2009: 23). In Nigeria, it is estimated that $68 \%$ of its population presently use the new media technology.

\section{The New Media and 2015 Elections in Nigeria}

During the 2015 general election in Nigeria, the traditional media and the new media played very important roles. The traditional media reported campaigns and other political activities, while the new media provided platforms and forums for public political debates and discussions, educated the voters and provided playgrounds for political interaction and participation. All these were aimed at strengthening and sustaining the nation's democracy. While recognizing the role of the new media in the 2015 election in Nigeria, the International Foundation for Electoral Systems (IFES) independently deployed the new technology in its quest to support credible and transparent elections. Despite the advantages of the new media outlined above, the new media also have some disadvantages with regards to the character of the electoral processes. Recent illustrations of the negative effects of the new media technology in the electoral process were recorded in the 2007 Kenyan's presidential election. These negative effects triggered the outbreak of violence during which about 1,133 lives were lost and 600,000 persons rendered homeless.

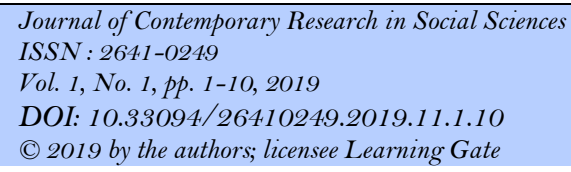


Udejinta (2011:13) submits that a private and biased media can shape elections, the electoral process and issues of election coverage and reporting. It can also negatively support of corporate interests and can provide propaganda for incumbent administrations, thereby, underplaying the importance of democratic principles. Information and communication technology have become a highly potent force in the transformation of social, economic, and political life of the people globally. Modern developmental strategies are based on the need for developing countries to embrace information technology both as a way of avoiding further economic and social marginalization as well as means of creating opportunities for growth, diversification, and sustainable development of their economies. The role of both old and new media in actualizing democracy globally cannot be overemphasized. The annulment of the June 12, 1993 election by General Ibrahim Babangida's regime tested the strength and effectiveness of the media. As at that time, media houses and journalists were able to sensitize the masses about the evils being perpetrated by the military junta and the elites who supported the annulment of the 1993 election which was considered to be one of the freest and fairest elections ever held in Nigeria. The Nigerian media made the Babangida's administration very unpopular and eventually Babangida bowed to this pressure by stepping aside on August 27, 1993.

However, the 2015 general election in Nigeria re-engineered the electoral process by the introduction of an attractive and very captivating aspect of electioneering that attracted a very large percentage of the docile youth population. The new media created opportunities for the young people on whom the 2015 elections were anchored especially by the opposition party to get involved in the electoral process. The engagement and participation of these youth was the "game changer" in the 2015 presidential election. Nigeria is a country of diverse contradictions and paradoxes which have defiled many political and economic theories. The build-up to the elections was very interesting. It was also described as one that had the most unethical campaign messages. The "Change" mantra of the opposition party was very outstanding (Tiawo, 2015: 4).

Muhamadu Buhari the Seventy two-year-old presidential candidate of the APC promised the nation a fresh start. The incumbent government made a big joke of this campaign promise of the opposition, wondering what kind of a fresh start the opposition presidential candidate could possibly offer the nation. To paraphrase this, the very acerbic wife of President Jonathan, Patience, claimed that Buhari and his APC party were "analogue in a digital era". Nonetheless, by the time the votes were being collated and counted, it became quite clear that for the first time in Nigeria's democratic history, an opposition party was taking over from an incumbent leader. Where Buhari had lost in his previous attempts, he won rather convincingly. After the elections, hypothetical questions were asked about the factors responsible for his victory at the polls.

A very outstanding factor that accounted for the victory of the opposition party in the 2015 elections was the increased participation of the youth in the electoral process. Another factor was how these participations leveraged on the potentials of the tools of the new media platforms like Twitter, Facebook, WhatsApp etc. The public relations firm that gave Buhari the leverage that won the election was owned and ran by a group of young people and $\mathrm{Mr}$ President acknowledged their contribution to his victory in his inaugural speech "the youths came out in thousands and supported my election, they gave their time and resources through social media and as private citizens donated between $\mathrm{N} 100-\mathrm{N} 1000$ each to finance my campaign or worked as unpaid volunteers who went from to town converting undecided voters". The contributions of the youth swung lots of voters in favour of the opposition in this election. Though, older people had claimed that elections were not won on social media. Online interactions stimulated youths to get more actively involved in the political process. President Buhari in his inaugural speech also said: "I thank the youths who worked tirelessly and carried the campaign on the social media".

A high percentage of users of the new media worldwide are young people. Although the percentage of the new media users is still very low in Nigeria when compared to what is obtained elsewhere. For instance, Lagos the most populous city in Nigeria has only a 30\% ratio new media usage. It is now very clear from the result of the 2015 election that while politicians paid little or no attention to the young population, these young people are now willing to take their destinies in their own hands by leveraging on the potentials created by the new media to actively participate in politics.

On the day of the election, these young people along with their parents who are tired of catering for their grown-up unemployed youths braved the threats of insurgency especially in the North East, endured the cumbersome electoral processes and voted for the candidates of their choice. The election results indicated that Nigerians were dissatisfied with the ruling People's Democratic Party (PDP). They were willing to give a former military ruler in his seventies a chance to repair the country that they claimed have been extremely impoverished and destroyed by the ruling party in the past sixteen years. The big question is how were these young people able to convince Nigerians to believe and have hope in the change agenda of Muhamadu Buhari.

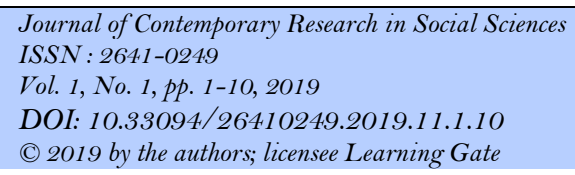


The 2015 election was a turning point in the Nigerian's democratic journey. The youth perception about participation in politics was changed by the awareness created through the new media. The youth came to the realization that their votes could actually count and that they have everything at stake by determining how their country would be run. Barely hours to the conclusion of the election, were the results instantly declared on the new media platforms in celebrations of the victory of the opposing party.

\section{Impact of the New Media on the Election Victory}

The 2015 general election in Nigeria was another manifestation of the potency of the new media. In this election, the new media was used positively by the young people. Before the 2015 elections, the percentage of young Nigerians who were interested in elections and the electoral process were very low. The Nigerian youth whose population was estimated at about 90 million had apathy towards politics and the political processes, despite the fact that the political process would go a long way in determining their future. Young Nigerians preferred spending days on queues to audition for reality shows like "Big Brother, Project Fame, etc, than bother queueing up to register and vote in elections or take part in the country's electoral process. But in 2015 the reverse was the case, more people below the age of 35 years got involved in determining who rules them and how they emerged. The youth suddenly came to realize the importance of their numerical strength in determining who emerges as the president of their country and how their involvement in politics and the political process could change the fortunes of their country to their advantage. Despite the fact that accurate statistics of youth involvement in the political process remain unavailable, it was clear that in 2015 more youths picked up the gauntlet which in this case was the social media and got into mainstream of politics. Gallagher (2015: 3) opines that this development swayed to the advantage of the opposition party and eventually aided their victory at the polls.

General Buhari who before his emergence as the APC presidential flag bearer was perceived as a harsh and an ascetic dictator, got a facelift and was given a less austere demeanour by his public relations team which were made up of predominantly young people made. His PR made very effective use of the new media in laundering his image and eventually made him victorious at the polls. Buhari who was before then preserved as a "Religious Extremist and Wicked Dictator" and whose primary motive was to Islamize Nigeria", suddenly appeared on billboards wearing a tuxedo and sporting smiles. He met with the young people consistently wherever he went to during town hall meetings and various interactive sessions. This resulted in the fact that young people who were infants during his 20-month severed rule of in 80's were moved to join in the spread of his change gospel. They also bought the claim that the incumbent government was very corrupt, stagnated and drove the country to dire economic strains through the new media, (Samer-Elchahabi, 2015: 7). Notwithstanding the negative publications, videos, voice notes and broadcast of hate speeches credited to Buhari by the ruling party which ordinarily would have marred his political ambition and that of other APC bigwigs indicted in such publications. The new media held sway and eventually helped persuaded the people into voting Muhamad Buhari into power. Through the new media platforms information pertaining to the 2015 general elections in Nigeria were made accessible to every interested person. Loads of messages and information were disseminated and communicated to the public that would have sparked off violence and unrest in some volatile nations went viral before the day of the election. The new media, for example, was used to spread the message that convinced the public to believe that the reasons for the postponement of the elections from February 14, 2015, to March 28, 2015, was to the advantage of the ruling party, as against the claimed unpreparedness adduced by the Independent National Electoral Commission. This gave a huge advantage to the opposition and endeared the electorate compassionately to them. Dare (2015:6) contends that these reasons adduced through the new media made the public believe that the postponement of the election date was to the advantage of the ruling party as there was rancour and instability in the ruling party as at that time.

Nigeria held its presidential elections on the $28^{\text {th }}$ of March, 2015 and contrary to popular opinions and expectations, the elections were free, fair, devoid of the anticipated conflicts and violence. The election of Muhammadu Buhari as president of Nigeria was hailed by the international community as a historic peaceful transfer of power in Africa's most populous nation. The election was the first in the history of Nigeria as a sitting president was defeated by the opposition. The opposition party, the All Progressives Congress (APC) won the presidency and also took the majority of the seats in the Senate and House of Representative and also enjoyed wide support and acceptance from the citizens especially the young people.

As the electioneering campaigns built up, the presidential and vice presidential candidate of the opposition party opened accounts on Tweeter, Facebook and other new media platforms, made their presence known and

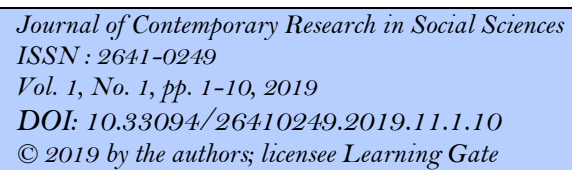


interacted with the youths directly through these platforms. The issues raised by youths were responded to and the candidates were able to sell their programs, manifestos, ideas and policies directly to those that mattered. Posts were favourited, tweeted and re-tweeted by thousands of young people and the ripple effect of this gave the young voters access to information on the go and motivated them towards making up their minds easily as to whom to cast their votes for. Several campaigns soliciting for votes for the opposition's presidential candidate were also started by young people in which they became volunteers, joined the campaign train and actively canvassed for votes for their preferred candidate i.e. the opposition. The "Change" slogan floated by the opposition party at its rallies and campaigns were widely embraced by all through the new media platforms. Live discussions, virtual realities posts of town hall meetings that were held on regular basis were ever-present on the cyberspace via the new media platforms. People for the first time were able to air their opinions on contemporary issues about the 2015 election and the electoral system both within and outside the country. Most people especially the youth spent most of their time on the new media platforms and the internet persuading people to vote for the opposition party (Elechababi 2015:3).

On the day the results were being announced most parts of the country had no electricity. Despite this shortcomings, people were able to follow the trends of the election and shared information and results as they were being released at the polling booths via the new media technology. The prompt and timely dissemination of the information about the election and the results made it possible that the outcome of the election was in public domain instantly. The new media played a much bigger role in the reporting of election results unofficially, mapping and reporting troubled spots and shared users' individual voting experiences. In his view, Udejinta (2011: 7) asserts that the new media constituted one of the battleground in the 2015 election in Nigeria.

The new media has become an inseparable part of human life in places where they exist. The technology has prompted the evolution of new forms of democracy, government, and has become a clear and more effective voice for many especially the youth. In fact, the new media has influenced all spheres of human life. The use of the new media has grown tremendously since its discovery. The success of the new media technology is attributed to its flexibility and other unique factors that make its application and usage very consistent, easy and friendly. Instead of restricting its networks to a particular product and manufacturer, the new media technology allows interconnectivity from any kind of compatible device. No network is too large or too small, too fast or too slow to be interconnected. Thus, the new media includes inexpensive networks that can only connect a few computers within a single room as well as expensive networks that can span over continents connecting thousands of computers, smartphone and other devices globally.

The 2015 elections in Nigeria witnessed a remarkable use of new media technology as a tool for political communication, interaction, mobilization and participation. The new media was at the disposal of both the candidates and the electorate. It was used for campaigns via personal websites, blogs, group chats, facebook, twitter, and other new media platforms, and as a means for fostering political activities and participation. Apart from this, the new media was equally used as a tool to undermine and even destroy the images and aspirations of political opponents especially the People's Democratic Party in the general election. According to Eddings (2015: 2) "the new media will play important role in Nigeria's democracy in the coming years with the rising rate of internet penetration in the country".

\section{Prospects and Challenges of the New Media Technology}

The use of new media in politics includes the use of Twitter, Facebook, YouTube, What's app, we chat and Instagram etc. These new media platforms have dramatically changed the face and approaches to elections and electioneering campaigns and how the electorate interact with the politicians. The predominance of social media in politics have made the elected officials and candidates seeking election into public offices more accountable and accessible to the voters. The ability to publish contents and broadcast it to millions of people instantaneously is a major advantage of the new media. The new media allows campaigns to carefully manage a candidates' image based on its rich real-time programs and content analysis made available to the electorate at almost no cost. The new media has changed Nigerian politics in many ways. One of the most outstanding features of the new media is the fact that it provides the citizens with the much sort opportunity to express their opinions, criticize or praise any government and its policies without the fear of being traced and arrested. Politicians and government officials that were being misled by praise singers and political sycophants are poised to see first-hand how the electorate feels about them and their reactions to their policies and programs through the new media platforms.

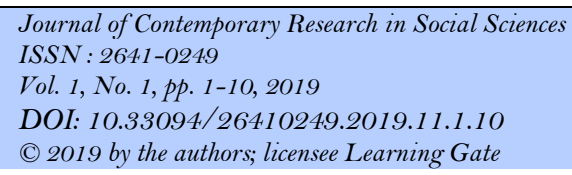


It is a very clear fact that most internet accounts do not have genuine addresses or the real names of its owner, thus making it difficult for the individuals that express their opinion through this medium to be traced. Contemporary issues in our society have on several occasions proved that issues criticized in the new media platforms have been received by those being criticized, and this had in most cases influenced their actions in favour of the public as they cannot identify those criticizing them. Opinions are expressed freely and wholly in new media since the originators know for sure that such expressed opinion cannot be traced back to them or can any anybody come after them for expressing these opinion. This is very healthy for every democracy (Dukor 1999:15). The choice of the new media as a political tool is also informed by the fact that it represents the most efficient, credible and reliable means of conducting opinion polls and it is also very cost effective. Before the final result of the 2015 presidential election in Nigeria were announced, most people already knew who won the election as comments on the outcome of the election at various polling stations were posted on the new media platforms. This process was very transparent and reliable as the information was relayed first hand and as they occurred. Again, the use of the new media is ideal because people made comments from their comfort zones. They use the platform from wherever they are and from wherever they liked. Politicians spend little or nothing in interacting and disseminating information about their political events, activities and programmes. They don't worry about the cost of these interactions, meetings, debates on the new media since more than $75 \%$ of the electorate are already on the internet. The new media, therefore, offers the best machinery for measuring opinion polls. The outcome of the elections are known as soon as the poll ends and this process is almost free, credible, transparent, it saves time and it is very cost effective, (Madueke 2017: 9). It has been aptly proved that the internet has created a "society" within the society where we live. People live on the internet the same way they live in the society and an average internet user touches his device once in every ten minutes, which is more often than one touches any other device (Joseph Pulitzer 2016:12).

\section{Major Advantages of the New Media Technology}

These include the following:

- The new media technology provides platforms through which individuals irrespective of tribe, religion, sex, educational background and party affiliations etc. can be reached within the shortest possible time without sentiment or discrimination.

- The new media makes it possible for a large audience, scattered all over the country and even beyond to be reached at the same time without geographical limits or boundaries.

- The new media provides a platform for the target audience to be reached at almost a zero cost. The huge sum that is usually spent in mobilization is reduced. This advantage has a significant impact in enhancing massive political mobilization, political participation and is acclaimed to have prompted the victory of the APC in the 2015 presidential election in Nigeria (Udensi, 2015:2).

Key avenues through which the new media technology influenced the electoral victory in the 2015 election.

- The new media created access for direct contact with the voters;

- It made the campaigns and electioneering activities viral and gave prompt information about political events, discussions, reactions and unofficial election results instantaneously;

- It created avenues for tailored political messages to be directed to the target audience directly;

- The new media enhanced fundraising for political activities;

- Made easy feedback mechanisms possible from both the candidates and the electorates;

- The new media prompted an easy mechanism for weighing public opinion and reactions;

- The new media is hip and trendy thus captivating the interest of young people;

- The new made it possible for many that would not have bothered about what went on in the political circle to participate actively in political activities;

- The new media helped in maintaining and sustaining party ideology, slogans and ensuring consistency of ideas and conversations;

- Created instant avenues for resolving political issues between the candidate and the electorate; 
- The newly created and built trust between the politician and their supporters are sustained as the politicians and electorates are constantly in touch through new media platforms, (Michelle Goodle, 2015).

The impact of the new media technology on electoral victory in Nigeria with regards to the 2015 general election was overwhelmingly in favour of the APC. However, this technological innovation can also have a very negative and devastating impact if wrongly applied as it also has numerous challenges which include:

- The uncensored nature of messages and information disseminated through the new media can generate lots of controversies which can take a very long time and efforts to be resolved;

- The Independent National Electoral Commission (INEC) is mandated and trained to conduct and announce election results. Announcing elections results unofficially through new media platforms can incite violence and upturn the gains of the whole electoral process when these results are announced without recourse to its impact on the whole nation;

- Personal interests, gullibility and emotion rule the themes of most messages shared on the new media, these messages lack ethics, professional touch;

- It is on record that about $75 \%$ post-electoral violence in Africa in the past ten years were stirred up by messages and information shared on the new media;

- Most users of the new media assume different personalities and their names and contact addresses cannot be traced. This is a major disadvantage of the new media as the validity and reliability of most information on the new media cannot be guaranteed;

- Our laws are still unable to substantiate appropriate punishments for the new media related offences as it is almost impossible to trace and established the origin of their sources.

\section{Conclusion}

The role of media in politics in Nigeria cannot be over-emphasized. As the world moves from what used to be to the analogue to the digital era. Nigeria should not be left behind. Nigerians should arise and use the new media technology to full advantage. As a developing country, the new media can help in cutting down the cost of seeking public offices and to also ensure that the will and choice of the people prevail and that election promises are translated into policies that will benefit the entire citizens. The new media offers participatory democracy at its best, it promotes transparency, efficiency, accuracy and greater participation of the electorates in the political process. As the current administration in Nigeria owes its victory at the 2015 polls to the youth with the aid of the new media. Incoming administrations might as well be prepared to gamble in a like manner. The freedom the cyberspace offers will eventually be deployed and accessed by lots of Nigerians in future and a listening government that will interact and engage Nigerians especially the youth positively through the new media will not only win elections due to the advantages of the new media but will also enjoy better solidarity and support from Nigerians.

\section{References}

Adibe, O \& Chibuwe, O. (2011). Social Media, Electioneering and Sustenance of Democracy in Africa: A SWOT analysis. A Paper Presented at the African Media and Democracy Conference (AMDC), Accra, Ghana.

Anaeto, O. and Osifeso, E. (2008). Models and Theories of Communication. Lagos: African Renaissance Books Incorporated.

Baxter, T. (1996). The Media and Elections. New York: New Age Publishers.

Chukwu, P. (2007). The 1999 Constitution and the Independent National Electoral Commission (INEC): Prospects for Impartial Supervision and Conduct of Elections. In Jega Attahiru and Oke, I (Eds.) Elections and the Future of Democracy in. Nigeria: Nigerian Political Science Association.

Dare, S (2015). Social Media Best Practice. London: Hillcrest Publishers.

Dara, S. (2015). Africa in the Age of Social Media. Oxford: University Press.

Dare, S. (2015). Historic Replacement of Power, International Centre for Journalism in Nigeria.

Dukar, C. (1999). Constitutional and Moral Bases of the Role of the Media in Politics and Governance. London: Ant Hill Publisher

Eddings, J. (2015). The power of Social Media in Elections in Nigeria. Lagos: Pentagon Books

Elechababi S. and Gallagher A (2015). The Media and Democracy. Huston: Dexta Publishing Co.

Elechababi, S. (2015). Electoral Reporting. Huston: Dexta Publishing Co. 
Ellis, M. (2006). Electoral Campaigns has taken a New Dimension. Atlanta: Evilly Books.

Gallagher, A. (2015). How the Social Media won the Election that Shocked the World. London: University Press.

Godfrey, M. (2015) Public Relations and the Nerw Media An Overview. Michigan: Denman Press.

Graber, D. (2009). No Penalties on Wrong Doing on the Social Media, Dexta Books, Maryland

Johnson, C. and Kagool, J. (2013). How Social Media is Impacting Elections. London: Mac-Millan Books

Madueke, B. (2017). Substance of Politics. New Delhi: Oxford University Press Plc.

Michael, K. (2005). The American Electorate and the Social Media. New York: Imaginary House Publishers.

Microsoft Encarta (2009). News approaches in media communication.

Oji, O.R. (1997). An Introduction to Political Science. Enugu: Mary Dan Publishers

Pulitzer J (2016). Auditing the Social Media, Wellington: Great Books

Sirjaibi, L. (2015). The Touths and 2015 Elections in Nigeria. Lagos: Chatham House

Tiawo, J. (2015). How Social Media Played a Role in Nigeria 2015 Elections. Lagos: New ideal

Publishers.

Udejinta, M.A. (2011). Uses of SMS in Campaigns: An Assessment of 2011 General Elections and Post-Election Violence in Northern Nigeria, in Des Wilson (Eds.) The Media, Terrorism \& Political Communication in Nigeria. ACCE Books, Uyo.

Udensi, E.U. (2015). The New Media and Electoral Victory, Ibadan: Abic Books

Yankavich K. (2005). The New Media and Victory at the Poles. The American Perspective. New York: Strand Publishers

Yakubu, A. S. (1993). MKO Abiola and the Annulled 1993 Presidential Election. Daily Times December $14^{\text {th }}$. 